\title{
The Effectiveness of Photobiomudulation Therapy (PBMT) in COVID-19 Infection
}

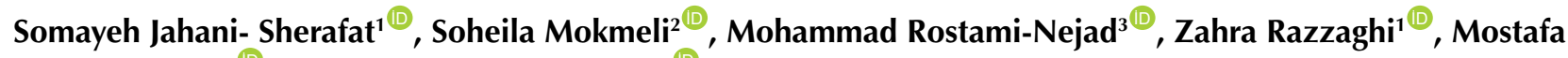 \\ Rezaei Tavirani $^{\circledR}$, Mohammadreza Razzaghi ${ }^{1 *}{ }^{(\mathbb{D}}$ \\ 'Laser Application in Medical Sciences Research Center, Shahid Beheshti University of Medical Sciences, Tehran, Iran \\ ${ }^{2}$ Canadian Optic and Laser Center (Training Institute), Victoria, BC, Canada \\ ${ }^{3}$ Gastroenterology and Liver Diseases Research Center, Research Institute for Gastroenterology and Liver Diseases, Shahid \\ Beheshti University of Medical Sciences, Tehran, Iran \\ ${ }^{4}$ Proteomics Research Center, Shahid Beheshti University of Medical Sciences, Tehran, Iran
}

\section{*Correspondence to \\ Mohammadreza Razzaghi, Laser Application in Medical Sciences Research Center, Shahid Beheshti University of Medical Sciences, Tehran, Iran. Email: morazzaghi@gmail.com}

Published online December 30 2020

\begin{abstract}
Introduction: Currently, the COVID-19 pandemic is an important health challenge worldwide. Due to the cytokine storm, the mortality rate in acute respiratory distress syndrome (ARDS) is high, but until now no therapy for these patients was approved. The aim of this review was to discuss the possible anti-inflammatory effect of photobiomodulation therapy (PBMT) on ARSD patients and present the potential role of low-level laser therapy (LLLT) in the improvement of respiratory symptoms associated with the severe acute respiratory syndrome coronavirus 2 (SARS-CoV-2).

Methods: Studies about PBMT in inflammation and ARSD patients were examined. A primary search with reviewing English-language citations between 2005 and 2020 using the keywords COVID-19, ADRS, cytokine storm, low-level laser therapy, anti-inflammatory, and photobiomodulation was performed. The initial search yielded 818 articles; however, 60 articles were selected and discussed in the present study.

Results: The results of the selected studies showed the usefulness of PBMT in the treatment of inflammation and ARSD in patients with COVID-19 infection. This therapy is non-invasive and safe to modulate the immune responses in ARSD patients.

Conclusion: PBMT can potentially reduce the viral load and bacterial super-infections in patients with COVID-19 infection and control the inflammatory response. Therefore, the use of PBMT could be an efficient strategy for preventing severe and critical illness in SARS-COV2 infection.

Keywords: COVID-19, Photobiomodulation, Acute respiratory distress syndrome, Cytokine storm, Low-level laser therapy.
\end{abstract}

\section{Introduction}

The 2019 novel coronavirus (COVID-19) or the severe acute respiratory syndrome coronavirus 2 (SARS-CoV-2) is rapidly spreading around the world. ${ }^{1}$ Coronaviruses are enveloped positive-sense RNA viruses. ${ }^{2}$ RNA viruses create an important hazard to human health and are more disposed to changes and mutations compared with DNA viruses. $^{3}$ Coronaviruses are shown to cause mild and mainly upper respiratory infections (common cold) as usual, but SARS (severe acute respiratory syndrome) and Middle East Respiratory Syndrome (MERS) cause severe and frequently lethal outbreaks of respiratory infections. After SARS and MERS, SARS-CoV-2 has been the latest coronavirus pandemic. ${ }^{1}$ The symptoms of SARS-COV2 are wide, from asymptomatic and mild in most people to acute respiratory distress syndrome (ARDS) and multiorgan dysfunction. The mortality rate in ARDS is around 25 to $40 \%{ }^{4}$ Symptoms like fever, cough, sore throat, breathlessness, fatigue, muscle soreness, malaise is more common in the infected patients, but for $25 \%-30 \%$ of affected patients, intensive care admission is necessary. ${ }^{1,4}$ The fatality rate in the community is estimated to range from 2.5 to $3 \%$ but up to $11 \%$ of hospitalized adult patients and more than $30 \%$ of ICU admissions. ${ }^{5,6}$ SARS-CoV-2 spreads principally via the respiratory route. Although SARS-COV2 RNA has been detected in fecal samples, there is not any report of fecal transmission. ${ }^{7}$ The virus can be transmitted by respiratory droplets or aerosols of infected people and attachment to mucosal surfaces. High temperature, low humidity and sunlight are the most important environmental factors that could reduce the viability of aerosols; therefore, SARS-CoV-2 virus transmission alters in dissimilar geographical locations. ${ }^{8}$ The virus enters mucosal epithelial by angiotensinconverting enzyme 2 (ACE2) as the practical receptor. Although ACE2 mRNA is present in closely all organs,

Please cite this article as follows: Jahani- Sherafat S, Mokmeli S, Rostami-Nejad M, Razzaghi Z, Rezaei Tavirani M, Razzaghi M. The effectiveness of photobiomudulation therapy (PBMT) in COVID-19 infection. J Lasers Med Sci. 2020;11(suppl 1):S23-S29. doi:10.34172/ jlms.2020.S4. 
its protein expression is expressed in vascular endothelial, renal, cardiovascular tissue, and the small intestine. Interesting findings have shown that lung alveolar epithelial cells and enterocytes of the small intestine have large surface expression of ACE2 protein., ${ }^{1,9}$ The main target of SARS-COV-2 is not the respiratory system, as it has also tended to the digestive system, circulation system, urogenital system, and central nervous system. ${ }^{7}$

All people are at risk to this novel virus even children and newborns, but the elderly and people with underlying diseases, such as acute renal insufficiency, hypertension, diabetes, and cardiovascular disease, are more at risk of severe infection.,10 Despite extensive researches on coronavirus treatment, no specific antiviral treatment has been developed. Supportive and symptomatic treatment is essential for patients, but in patients with acute respiratory symptoms, hospitalization and provision of oxygen is necessary. ${ }^{1}$

Photobiomodulation therapy (PBMT), also known as cold laser therapy, low-level laser therapy (LLLT), biostimulatory laser therapy, etc. is a kind of laser therapy, which uses visible light, near-infrared light in the range of 450-1000 $\mathrm{nm}$, and acts by the photochemical reaction in cells. ${ }^{11}$ The experimental studies showed that PBMT stimulated mitochondria and produced signaling molecules such as ATP, cyclic AMP, NO and ROS and therefore could upregulate oxidative stress in cells and have an antioxidant effect. ${ }^{12}$ PBMT is applied to reduce pain, inflammation or edema and accelerate tissue repair. ${ }^{13,14}$ Also, there are several published reports about the satisfactory results of PBMT in combination with other conventional therapies in pneumonia and other respiratory disorders, which have similar symptoms to COVID-19 in the moderate and severe stage of disease. ${ }^{15-20}$

Therefore, in this review, we discussed the possible anti-inflammatory effect of PBMT on ARSD patients and presented the potential role of PBMT in the improvement of respiratory symptoms associated with SARS-COV2 by reviewing the published studies in this field.

\section{Materials and Methods}

Searches were performed in PubMed, Medline and Google Scholar for articles published in English and other bibliographic references from 2005 to 2020, and the following websites were searched: the WHO, CDC (Centers for Disease Control and Prevention), and NICE (National Institute for Health and Clinical Excellence, https://www.nice.org.uk/). The following keywords, alone or in combination, were also searched: "COVID-19," "ARDS," "cytokine storm," "low-level laser therapy," "antiinflammatory," and "photobiomodulation". Numerous studies regarding the SARS-COV-2 were published in 2020, and on the basis of the study scope, we categorized all papers into major categories including coronavirus pathology and cytokine cascade, PBMT and PBMT in pneumonia or ARDS. We found more than eight hundred published articles in the field of PBMT and COVID19, but 60 articles were selected and discussed in the present study.

SARS-CoV-2 Pathogenesis and Inflammatory Cascade The clinical features of COVID-19 are wide from asymptomatic to ADRS and multi-organ dysfunction (Table 1). ${ }^{21,22}$ In recent studies, lymphopenia and elevated inflammatory cytokines in most SARS-CoV-2 cases have been reported. ${ }^{23,24}$ It is a hypothesis that the activation of the apoptosis signaling pathway in lymphocytes in COVID-19 patients may lead to lymphopenia. ${ }^{25}$

Critical clinical manifestations and mortality in coronavirus patients are mostly developed in the late stage of the disease and it is due to the hyperactive immune reactions during viral infection. The first line of defense against viral infection is innate immune response stimulated by reactive oxygen species, secretion of primary cytokines and chemokines such as proinflammatory interleukins (IL1B, IL6), interferon (IFN), C-C Motif chemokine ligands (CCL2, CCL3, CCL5) and Nuclear Factor kappa-light-chain-enhancer of activated B cells (NF-kB) from epithelial cells, dendritic cells and macrophages. ${ }^{23}$ Nevertheless, an extreme

Table1. COVID-19 patient's symptoms and immune responses

\begin{tabular}{|c|c|c|c|c|c|c|}
\hline Classification & Asymptomatic & Mild & Moderate & Severe & Critical & Ref. \\
\hline Clinical symptoms & $\begin{array}{l}\text { Without clinical } \\
\text { symptoms and signs }\end{array}$ & $\begin{array}{c}\text { Acute upper respiratory } \\
\text { tract infection }{ }^{\mathrm{a}} \text { or } \\
\text { digestive symptoms }\end{array}$ & $\begin{array}{c}\text { Pneumonia, no obvious } \\
\text { hypoxemia with } \mathrm{CT} \\
\text { lesions }^{\mathrm{b}}\end{array}$ & $\begin{array}{c}\text { Pneumonia with } \\
\text { hypoxemia }{ }^{c} \text { with } \mathrm{CT} \\
\text { lesions }\end{array}$ & $\begin{array}{c}\text { ARDS and multi-organ } \\
\text { dysfunction }{ }^{\text {d }} \text { with CT } \\
\text { lesions }\end{array}$ & (21) \\
\hline Percentage & $20 \%$ & \multicolumn{2}{|c|}{$60 \%$} & \multicolumn{2}{|c|}{$10-20 \%$} & (24) \\
\hline Cytokines $\uparrow$ & normal & Moderate & Moderate & $\begin{array}{l}\text { proinflammatory } \\
\text { cytokine in plasma, } \\
\text { IFN- } \gamma, \text { GM-CSF }\end{array}$ & $\begin{array}{c}\text { higher proinflammatory } \\
\text { cytokine, especially in } \\
\text { IL-6 levels }\end{array}$ & (23) \\
\hline $\begin{array}{l}\text { Abbreviations: ARDS } \\
\text { acute upper respira } \\
\text { b CT lesions: Studies } \\
{ }^{b} \text { Hypoxemia: SpO2 } \\
{ }^{d} \text { Multi-organ dysfun } \\
\text { e Proinflammatory Cy } \\
\text { inflammatory proteir }\end{array}$ & $\begin{array}{l}\text { te respiratory distres } \\
\text { tract infection Sympt } \\
\text { wed, CT findings are } \\
\% \text {. } \\
\text { : encephalopathy, my } \\
\text { he: interleukin (IL)-6, } \\
\text { P) } 1 \alpha \text {, and tumor necr }\end{array}$ & $\begin{array}{l}\text { ndrome; GM-CSF, Gran } \\
\text { s: fever, fatigue, myalgia } \\
\text { re acceptable method i } \\
\text { ardial injury, heart failur } \\
\text { 10, granulocyte-colony } \\
\text { s factor (TNF)- } \alpha \text {. }\end{array}$ & $\begin{array}{l}\text { ulocyte-macrophage colc } \\
\text {, cough, sore throat, runn } \\
\text { patients with no typical } \\
\text { e, coagulation dysfunctio } \\
\text { stimulating factor (G-CSF }\end{array}$ & $\begin{array}{l}\text {-stimulating factor; IFI } \\
\text { nose, sneezing. } \\
\text { yymptoms of COVID-1 } \\
\text { and acute kidney injur } \\
\text { nonocyte chemoattrac }\end{array}$ & $\begin{array}{l}\text { Interferon gamma. } \\
\text { lisease. } \\
\text { t protein } 1 \text { (MCP1), }\end{array}$ & $g e$ \\
\hline
\end{tabular}


rise in proinflammatory cytokines and chemokines like IL2, IL7, IL10, granulocyte-colony stimulating factor (GCSF), Interferon-gamma-induced protein 10 (IP10), monocyte chemoattractant protein 1 (MCP1), macrophage inflammatory protein-1 alpha (MIP1A), Tumor Necrosis Factor alpha (TNFa), is associated with illness progression in patients with severe COVID-19. ${ }^{23}$ Afterwards, activation of NF-kB stimulates more proinflammatory cytokine production and induces apoptosis and necroptosis in severe infection. All of these signaling events may lead to increased cellular death, hyperinflammation, and the cytokine storm and eventually make multi-organ disorder (Figure 1). ${ }^{23-26}$ Therefore, efficaciously suppressing the cytokine storm is a key way to prevent the deterioration of patients with COVID-19 infection.

\section{Prevention and Treatment}

Treatment is essential support and depends on the illness grouping and the variation of symptoms. ${ }^{24}$ Stringent quarantine is necessary to prevent the transmission of the virus to others in all groups. All patients should be isolated at home and fully briefed about the risk markers for the prevention of this infectious disease. ${ }^{27}$ The standard supports are necessary to dehydration and malnutrition. ${ }^{28}$ Fever, cough and oxygen saturation should be controlled. Antibiotics should be prescribed in confirmed cases for the prevention of secondary bacterial infections. ${ }^{1,29}$ In hypoxic patients, the provision of oxygen is essential, depending on the patient's condition by a face mask or invasive/noninvasive ventilators. Antiviral drugs such as favipiravir, ribavirin, lopinavir, ritonavir are used based on the experience with SARS and MERS. However,

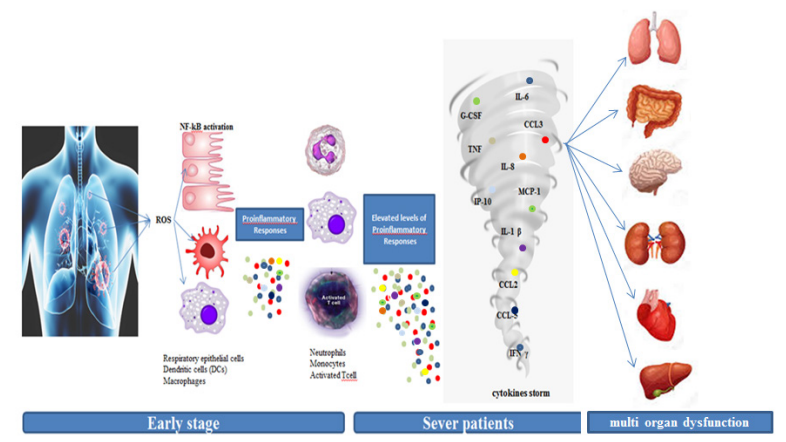

Figure 1. Cytokine Storm in Response to COVID-19. The SARSCOV2 attaches to lung epithelial cells and alveolar macrophages by the angiotensin-converting enzyme (ACE2). ACE2 downregulation and the loss of ACE2 from the endothelium enhance inflammation and vascular permeability by the induction of ROS and TNF- $\alpha$. Pro-inflammatory cytokine and chemokine activated more neutrophils and macrophages and activated T-cell and excessive immune response and started the cytokine storm. Eventually these events may damage to the respiratory system and advance the disease towards ARDS or multi-organ dysfunction. currently, there is no evidence to support specific drug treatment against COVID-19. ${ }^{27,29}$

Against COVID-19 infection, some hypothetical treatment strategies are recommended for cytokine storm suppression and the usage of some mediators for inhibited inflammation, such as Corticosteroid therapies, IL-1 family antagonists, IL-6 antagonists, TNF blockers, IFN$\alpha \beta$ inhibitors, ulinastatin (a natural anti-inflammatory substance in the body). Some drugs like baricitinib and ruxolitinib are powerful anti-inflammatories that inhibit the JAK-STAT signaling pathway and are approved for rheumatoid arthritis and myelofibrosis. The JAK-STAT signaling can activate STATs, which can attach to DNA and permit the transcription of genes involved in immune cell division, survival, activation and recruitment. Baricitinib and ruxolitinib inhibit the consequences of the elevated levels of cytokines. ${ }^{23,30}$ In addition, blood purification treatments by dialysis or improved vascular permeability with drugs could reduce the occurrence of a cytokine storm. ${ }^{23}$ Since many mortality rates in most cases are due to ARDS and cytokine storm, all suggested methods help patients balance the immune responses. Recently, PBMT and the use of X-ray radiation that is less than the maximum annual radiation dose have been suggested for the treatment of pneumonia associated with SARS-COV2. ${ }^{31,32}$

\section{Use of PBMT in Pneumonia Patients}

PBMT involves the use of wavelengths of light energy (450-1000 nm) in medicine, and apply low-level light on the surface of the skin for the treatment of some medical disorders like inflammation, pain management and the tissue healing process by altering cellular function. ${ }^{33}$ PBMT has been approved in several medical administrations and professional societies such as the World Association of Laser Therapy (WALT) and the North American Association for Photobiomodulation Therapy (NAALT). Laser therapy has been suggested for several chronic diseases and approved by the FDA to put the brakes on hair loss, pain management and decrease in fat accumulation. ${ }^{11}$

The first record of light therapy as a medical treatment returns to the time of Egyptian Pharaohs as shown by the inscriptions. ${ }^{34}$ The documents showed sunlight was effective in reducing flu-related mortality and morbidity in 1918 when the H1N1 flu was pandemic. ${ }^{35}$ Furthermore, natural or stimulated sunlight has a negative effect on the survival of various viruses, and viruses like influenza significantly lose their infectivity in the face of sunlight, as evidenced by research studies. ${ }^{8,36}$

In PBMT, the photon penetrates to the tissue, where it interacts with the intracellular biological molecules, and this starts a series of changes in cellular functions, including changes in cell membrane permeability and metabolism and it up-regulates antioxidant defenses and 
decreases oxidative stress. ${ }^{37}$ There are several hypotheses for the effects of PBMT on cellular functions. The first hypothesis refers to the cytochrome $c$ oxidase, which takes place in near-infrared light. Another theory is that the photons separate nitric oxide from the enzyme and make an active $\mathrm{NO}$ and increase electron transportation, mitochondrial membrane potential and ATP production. The next hypothesis is related to light-sensitive ion channels which lead to the accumulation of calcium in cells. After the absorption of photons, several signaling pathways are activated using reactive oxygen species (ROS), cyclic AMP, $\mathrm{NO}$ and $\mathrm{Ca}^{2+}$, eventually leading to the stimulation of transcription factors. Activated transcription factors can increase gene expression and as a result, enhance protein synthesis and proliferation, anti-inflammatory signaling, anti-apoptotic proteins and antioxidant enzymes. ${ }^{12,38}$

The studies indicate that PBMT suppresses inflammation by reducing ROS and NO in oxidative stress conditions and decreasing NF-kB in pathological situations. ${ }^{12}$ Also, PMBT decreases pain related to inflammation by the reduction of prostaglandin E2 and pro-inflammatory cytokines such as IL-1, IL-6 and TNFa concentration. ${ }^{31}$
Furthermore, PMBT cleans inflammatory fragments from the damaged tissues and enhances blood flow by the cellular influx of neutrophils, oxidative stress, edema, and bleeding. ${ }^{39}$

Since 1978, the results of different studies have indicated that "PBMT could be used in respiratory tract diseases". Several experimental studies in humans and animals have demonstrated that PBMT potentially moderate lung inflammation, fibrosis, pneumonia, and acute respiratory disorders. ${ }^{40}$ PBMT therapy increases microcirculation, lymphatic drainage, cellular metabolism, healing promotion and tissue regeneration, thereby alleviating many acute and chronic conditions (Table 2). Therefore, PBMT has the possibility of suppressing ARDS, as a major reason for mortality in the COVID-19 pandemic. ${ }^{40}$

On the other hand, some studies have shown that monochromatic blue light (400-470 nm) has an antimicrobial effect on numerous bacterial and viral infections and therefore, the solicitation of this laser level could be effective in reducing super infection associated with respiratory viral infection like SARS-COV2 and reducing the virus load in patients. ${ }^{41-44}$ In a study by Shehatou et al., it was shown that $P$. aeruginosa, S. aureus,

Table 2. Previews Studies on LLLT Effects on Respiratory Tract Diseases

\begin{tabular}{|c|c|c|c|}
\hline Author & Patients/Animal & Kind of Laser Therapy & Results \\
\hline Mohamed et al (15) & 31 patients with chronic respiratory disorder & Acupuncture laser & Improvement in clinical symptoms \\
\hline Lutai et al (17) & Pneumonia in elderly patients & infrared laser therapy & Rehabilitation \\
\hline Sayed et al (16) & 30 COPD patients & LLLT & Clinical improvement \\
\hline Milojevic et al (18) & 50 patients with asthma & acupuncture & $\begin{array}{l}\text { Improvement of all estimated lung function } \\
\text { parameters }\end{array}$ \\
\hline Suzuki et al (19) & 30 COPD patients & acupuncture & Improvement in Borg scale \\
\hline Ailioaie et al (54) & 98 children with moderate or severe asthma & acupuncture & $\begin{array}{l}\text { - Improvement in immunological and clinical } \\
\text { parameter }\end{array}$ \\
\hline Ostronosova et al (55) & 466 patients ( bronchial and asthma:BAni) & $\begin{array}{l}\text { low-intensive laser } \\
\text { radiation }\end{array}$ & $\begin{array}{ll}\text { - } & \text { Improves a BA course } \\
\text { - } & \text { Reduction in the duration of hospitalization }\end{array}$ \\
\hline Amirov et al (56) & 142 patients with pneumonia & $\begin{array}{l}\text { low-energy laser with } \\
\text { drugs }\end{array}$ & $\begin{array}{ll}\text { - } & \text { Discount in cell membrane permeability } \\
\text { - } & \text { Increased blood iron chromium } \\
\text { - Improvement of respiration function }\end{array}$ \\
\hline Kochetov et al (57) & 19 patients with acute pneumonia & $\begin{array}{l}\text { low-energy laser with } \\
\text { common drugs }\end{array}$ & $\begin{array}{l}\text { - } \quad \text { Discount of pain, cough heaviness in the chest } \\
\text { - } \quad \text { More rapid normalization of respiration function } \\
\text { Decreased hospitalization time. }\end{array}$ \\
\hline Sigman et al $(50,51)$ & 2 patients with Severe COVID-19 Pneumonia & PBM therapy & $\begin{array}{l}\text { - } \quad \text { Increased in Oxygen saturation } \\
\text { - } \quad \text { CRP normalized } \\
\quad \text { Pneumonia Severity Index improved from Class } \\
\quad \text { to Class. }\end{array}$ \\
\hline Ambire et al (58) & Rat (LPS-induced pulmonary inflammation) & LLLT & Reduced the lung permeability \\
\hline da Silva et al (59) & Wistar rats were exposed to formaldehyde $1 \%$ & $\begin{array}{l}\operatorname{LLT}(660 \mathrm{~nm}, 12.86 \mathrm{~J} / \\
\left.\mathrm{cm}^{2}\right)\end{array}$ & $\begin{array}{ll}\text { - } & \text { Reduced neutrophilic lung inflammation } \\
\text { - } & \text { Reduced myeloperoxidase activity } \\
\text { - } & \text { Reduced microvascular lung permeability } \\
\text { - } & \text { Alterations of inflammatory cytokines }\end{array}$ \\
\hline de Lima et al (60) & $\begin{array}{l}\text { Rats with bronchial hyperresponsiveness } \\
(\mathrm{BHR}) \text { and lung inflammation }\end{array}$ & $\operatorname{LLT}\left(660 \mathrm{~nm}, 7.5 \mathrm{~J} / \mathrm{cm}^{2}\right)$ & $\begin{array}{l}\text { - } \quad \text { Decreasing both TNF- } \alpha \text { and iNOS } \\
\text { - } \quad \text { Control the lung's inflammatory reactions. }\end{array}$ \\
\hline $\begin{array}{l}\text { da Cunha Moraes et } \\
\text { al (61) }\end{array}$ & $\begin{array}{l}\text { COPD mice (animals exposed to cigarette } \\
\text { smoke) }\end{array}$ & $\begin{array}{l}\text { Diode laser, } 660 \mathrm{~nm}, \\
3 \mathrm{~J} / \mathrm{cm} 2 \text { ) }\end{array}$ & $\begin{array}{ll}\text { - } & \text { lessen inflammatory cells } \\
\text { - } & \text { Decreased proinflammatory cytokine in BAI } \\
\text { - } & \text { Decreased collagen displacement }\end{array}$ \\
\hline
\end{tabular}


K. pneumoniae, and A. baumannii as four important nosocomial bacterial infections were highly susceptible to monochromatic blue light. ${ }^{45}$ Blue light in bacteria could block gene expression associated with DNA replication and cell division and the creation of free radicals like cytotoxic ROS and DNA mutation. ${ }^{46}$ Bacterial inhibitor doses have no significant effect on viability, function, and proliferation in mammalian cells. ${ }^{47}$

Several studies showed that PBMT was effective against viral infections. ${ }^{20}$ Lasers with different wavelengths can be valuable in viral infection. For example, green light lasers increased oxygenation in tissue and blue light used as photodynamic therapy (PDT). PDT is a two-stage action that syndicates light energy with a photosensitizer as a drug that considered to destroy cells after light stimulation. Treating these cells with PDT can also reduce the viral load and increase NO.

Lugongolo et al in 2017 showed that PBMT enhanced cell apoptosis in human immunodeficiency virus (HIV1) infected cells but had no inhibitory effects on HIV-1 uninfected cells. ${ }^{48}$

In 2018, Lago et al demonstrated that a combination of PDT and PBMT was effective against herpes simplex in the nose wing region. ${ }^{49}$ We should consider that PBMT is dose-response and acts according to the Arndt-Schulz dose curve which states that if the stimulus is too weak, no outcome is seen. An optimal dose leads to the best effect, while a higher dose inhibits the effects. Each wavelength has a specific effect on special treatment goals..$^{50,51}$

\section{PBMT in SARS-COV-2 Patients}

Two case reports have been published recently regarding the PBMT application on COVID 19 infection. The first was a 57-year-old man and the second was a 32-yearold woman, being morbidly obese, and both had severe COVID-19 infection with pneumonia. In these cases, SARS-CoV-2 had been confirmed by real-time PCR of the nasopharyngeal swab. The chest $\mathrm{X}$-ray and clinical observation (SpO2 of $80 \%$, oxygen requirements and blood tests) demonstrated lung involvement. Both patients received four once-daily PBMT (LLLT) sessions with 808 and $905 \mathrm{~nm}$ laser beams and were successfully treated (SpO2 increased to $97 \%-100 \%$, oxygen requirement decreased and the pneumonia severity index improved from class V to Class II CRP normalized). ${ }^{52,53}$

Although there have been just two studies reporting satisfactory effects of PBMT on patients with SARSCOV2 infection until now, more studies and clinical trials to estimate the clear effect of laser therapy are required.

\section{Conclusion}

The COVID-19 pandemic is a recent major pandemic challenge in the world. High virus titer and the subsequent cytokine storm due to strong inflammatory cytokine and chemokine responses and ARDS are the most important complications with high mortality, especially in immunosuppressed patients and those with underlying diseases, during SARS-CoV2 infection. There are no approved drugs or vaccines, so most attention is given to supportive care and the prevention of severe cases. Considering the experiences of SARS and MERS treatment, the controlled inflammatory response and the reduced viral load are efficient strategies to prevent severe and critical illness in SARS-COV2 infection. Evidence supports PBMT as a natural, non-invasive and safe method for modulating the immune responses at multiple levels and stimulating tissue healing. PBMT can potentially reduce the viral load and bacterial super-infections in patients with COVID-19 infections. ${ }^{20,51}$ However, there are not sufficient research studies regarding the effects of PBMT and COVID-19 disease. The application of PBMT at clinical stages needs different clinical trials to approve its effects on SARS-COV2 infection and the reduction of lung inflammation or pneumonia.

\section{References}

1. Singhal T. A review of Coronavirus disease-2019 (COVID-19). Indian J Pediatr. 2020;87(4): 281-286. doi: 10.1007/s12098-020-03263-6.

2. Fehr AR, Perlman S. Coronaviruses: An overview of their replication and pathogenesis. In: Maier HJ, Bickerton E, Britton P, editors. Coronaviruses: Methods and protocols. New York: Springer; 2015. p. 1-23. doi: 10.1007/978-14939-2438-7_1.

3. Zhao Z, Li H, Wu X, Zhong Y, Zhang K, Zhang YP, et al. Moderate mutation rate in the SARS coronavirus genome and its implications. BMC Evol Biol. 2004;4:21. doi: 10.1186/1471-2148-4-21.

4. Chaibakhsh S, Pourhoseingholi A, Vahedi M. Global incidence and mortality rate of COVID-19; special focus on Iran, Italy and China. Arch Iran Med. 2020;23(7):455461. doi: 10.34172/aim.2020.42.

5. Nikpouraghdam M, Jalali Farahani A, Alishiri GH, Heydari S, Ebrahimnia M, Samadinia H, et al. Epidemiological characteristics of coronavirus disease 2019 (COVID-19) patients in IRAN: A single center study. J Clin Virol. 2020;127:104378. doi:10.1016/j.jcv.2020.104378.

6. Russell CD, Millar JE, Baillie JK. Clinical evidence does not support corticosteroid treatment for 2019-nCoV lung injury. Lancet. 2020;395:473-5. doi: 10.1016/S01406736(20)30317-2.

7. Zhang Y, Geng X, Tan Y, Li Q, Xu C, Xu J, et al. New understanding of the damage of SARS-CoV-2 infection outside the respiratory system. Biomed Pharmacother. 2020;127:110195. doi: 10.1016/j.biopha.2020.110195.

8. Jayaweera M, Perera H, Gunawardana B, Manatunge J. Transmission of COVID-19 virus by droplets and aerosols: A critical review on the unresolved dichotomy. Environ Res. 2020;188:109819. doi: 10.1016/j.envres.2020.109819.

9. Hamming I, Timens W, Bulthuis MLC, Lely AT, Navis GJ, van Goor H. Tissue distribution of ACE2 protein, the functional receptor for SARS coronavirus. A first step in understanding SARS pathogenesis. J Pathol. 2004;203(2):631-637. doi: 10.1002/path.1570.

10. Wang L, He W, Yu X, Hu D, Bao M, Liu H, et al. Coronavirus 
disease 2019 in elderly patients: Characteristics and prognostic factors based on 4-week follow-up. J Infect. 2020;80(6):639-645. doi: 10.1016/j.jinf.2020.03.019.

11. Hamblin MR. Photobiomodulation or low-level laser therapy. J Biophotonics. 2016;9(11-12): 1122-1124. doi:10.1002/jbio.201670113.

12. de Freitas LF, Hamblin MR. Proposed mechanisms of photobiomodulation or low-level light therapy. IEEE J Sel Top Quantum Electron. 2016;22(3):7000417. doi:10.1109/ JSTQE.2016.2561201.

13. Cotler HB, Chow RT, Hamblin MR, Carroll J. The use of low level laser therapy (LLLT) for musculoskeletal pain. MOJ Orthop Rheumatol. 2015;2(5):00068. doi:10.15406/ mojor.2015.02.00068.

14. Bjordal JM, Lopes-Martins RA, Joensen J, Iversen VV. The anti-inflammatory mechanism of low level laser therapy and its relevance for clinical use in physiotherapy. Phys Ther Rev. 2010;15(4):286-293. doi: 10.1179/1743288X10Y.0000000001.

15. Mohamed AR, Shaban MM. Role of laser acupuncture in chronic respiratory diseases. Egypt J Chest Dis Tuberc. 2014;63(4):1065-1070. doi: 10.1016/j.ejcdt.2014.06.012.

16. Sayed MA, El-Sherif RM, Mohamed AR, El-Sherif AA. Low-level laser therapy in chronic obstructive lung disease. Egypt J Bronchol. 2018;12(3):317-322. doi: 10.4103/ejb. ejb_110_17.

17. Lutai AV, Egorova LA, Shutemova EA. [Laser therapy of elderly patients with pneumonia]. Vopr Kurortol Fizioter Lech Fiz Kult. 2001;3:15-18. [Russian].

18. Milojevic M., Kuruc V. [Low power laser biostimulation in the treatment of bronchial asthma]. Med Pregl. 2003;56(910):413-418. [Serbian].

19. Suzuki M, Namura K, Ohno Y, Tanaka H, Egawa M, Yokoyama $\mathrm{Y}$, et al. The effect of acupuncture in the treatment of chronic obstructive pulmonary disease. J Altern Complement Med. 2008;14(9):1097-1105. doi: 10.1089/acm.2007.0786.

20. Fekrazad R. Photobiomodulation and antiviral photodynamic therapy as a possible novel approach in COVID-19 management. Photobiomodul Photomed Laser Surg. 2020;38(5):255-257. doi: 10.1089/photob.2020.4868.

21. Wang D, Hu B, Hu C, Zhu F, Liu X, Zhang J, et al. Clinical characteristics of 138 hospitalized patients with 2019 novel coronavirus-infected pneumonia in Wuhan, China. JAMA. 2020;323(11):1061-9. doi: 10.1001/jama.2020.1585.

22. Chen N, Zhou M, Dong X, Qu J, Gong F, Han Y, et al., Epidemiological and clinical characteristics of 99 cases of 2019 novel coronavirus pneumonia in Wuhan, China: a descriptive study. Lancet. 2020;395(10223):507-513. doi: 10.1016/S0140-6736(20)30211-7.

23. Ye Q, Wang B, Mao J. The pathogenesis and treatment of the 'Cytokine Storm' in COVID-19. J Infect. 2020;80(6):607613. doi: 10.1016/j.jinf.2020.03.037.

24. Azkur AK, Akdis M, Azkur D, Sokolowska M, van de Veen W, Brüggen MC, et al. Immune response to SARSCoV-2 and mechanisms of immunopathological changes in COVID-19. Allergy. 2020;75(7):1564-1581. doi: 10.1111/ all.14364.

25. Xiong Y, Liu Y, Cao L, Wang D, Guo M, Jiang A, et al. Transcriptomic characteristics of bronchoalveolar lavage fluid and peripheral blood mononuclear cells in COVID-19 patients. Emerg Microbes Infect. 2020;9(1):761-770. doi: 10.1080/22221751.2020.1747363.

26. Chen AC, Arany PR, Huang YY, Tomkinson EM, Sharma SK, Kharkwal GB, et al. Low level laser therapy activates NF-kB via generation of reactive oxygen species in mouse embryonic fibroblasts. PLoS One. 2011;6(7):e22453. doi: 10.1371/journal.pone.0022453.

27. Jha AK, Kumar R, Goenka MK, Dayal VM. Emerging treatment and prevention strategies against COVID-19: A brief update. J Digest Endosc. 2020;11(1):69-72. doi: 10.1055/s-0040-1712547.

28. Bajwah S, Wilcock A, Towers R, Costantini M, Bausewein C, Simon ST, et al. Managing the supportive care needs of those affected by COVID-19. Eur Respir J. 2020;55:2000815. doi: 10.1183/13993003.00815-2020.

29. Chen ZM, Fu JF, Shu Q, Chen YH, Hua CZ, Li FB, et al. Diagnosis and treatment recommendations for pediatric respiratory infection caused by the 2019 novel coronavirus. World J Pediatr. 2020;16(3):240-246. doi: 10.1007/s12519020-00345-5.

30. Stebbing J, Phelan A, Griffin I, Tucker C, Oechsle O, Smith D, et al. COVID-19: combining antiviral and antiinflammatory treatments. Lancet Infect Dis. 2020;20(4):400402. doi: 10.1016/S1473-3099(20)30132-8.

31. Mokmeli S, Vetrici M. Low level laser therapy as a modality to attenuate cytokine storm at multiple levels, enhance recovery, and reduce the use of ventilators in COVID-19. Can J Respir Ther. 2020;56:25-31. doi: 10.29390/cjrt-2020015 .

32. Ghadimi-Moghadam A, Haghani M, Bevelacqua JJ, Jafarzadeh A, Kaveh-Ahangar A, Mortazavi SMJ, et al. COVID-19 tragic pandemic: concerns over unintentional "directed accelerated evolution" of novel Coronavirus (SARS-CoV-2) and introducing a modified treatment method for ARDS. J Biomed Phys Eng. 2020;10(2):241-246. doi: 10.31661/jbpe.v0i0.2003-1085.

33. Chung H, Dai T, Sharma SK, Huang YY, Carroll JD, Hamblin MR. The nuts and bolts of low-level laser (light) therapy. Ann Biomed Eng. 2012;40(2):516-533 doi: 10.1007/ s10439-011-0454-7.

34. Alpert JS. The Jeremiah Metzger lecture: Jeremiah Metzger and the era of heliotherapy. Trans Am Clin Climatol Assoc. 2015;126:219-26.

35. Schuit M, Gardner S, Wood S, Bower K, Williams G, Freeburger D, et al. The influence of simulated sunlight on the inactivation of influenza virus in aerosols. J Infect Dis. 2020;221(3):372-378. doi: 10.1093/infdis/jiz582.

36. Hobday RA, Cason JW. The open-air treatment of pandemic influenza. Am J Public Health. 2009;99(Suppl 2):236-242. doi: 10.2105/AJPH.2008.134627.

37. Boras VV, Juras DV, Rogulj AA, Panduric DG, Verzak Z, Brailo V. Applications of low level laser therapy. In: Motamedi $\mathrm{MH}$, ed. A Textbook of advanced oral and maxillofacial surgery. Rijecka, Croatia: InTech; 2013. p. 327-339. doi: 10.5772/52678.

38. Farivar S, Malekshahabi T, Shiari R. Biological effects of low level laser therapy. J Lasers Med Sci. 2014;5(2):58-62. doi: 10.22037/jlms.v5i2.5540.

39. Assis L, Moretti AIS, Abrahao TB, Cury V, Souza HP, Hamblin MR, et al. Low-level laser therapy (808 nm) reduces inflammatory response and oxidative stress in rat 
tibialis anterior muscle after cryolesion. Lasers Surg Med. 2012;44(9):726-735. doi: 10.1002/lsm.22077.

40. Enwemeka CS, Bumah VV, Masson-Meyers DS. Light as a potential treatment for pandemic coronavirus infections: A perspective. J Photochem Photobiol B. 2020;207:111891. doi: 10.1016/j.jphotobiol.2020.111891.

41. Dai T, Gupta A, Huang YY, Yin R, Murray CK, Vrahas MS, et al. Blue light rescues mice from potentially fatal Pseudomonas aeruginosa burn infection: efficacy, safety, and mechanism of action. Antimicrob Agents Chemother. 2013;57(3):1238-1245. doi: 10.1128/AAC.01652-12.

42. Halstead FD, Thwaite JE, Burt R, Laws TR, Raguse M, Moeller R, et al. Antibacterial activity of blue light against nosocomial wound pathogens growing planktonically and as mature biofilms. Appl Environ Microbiol. 2016;82(13):4006-4016. doi: 10.1128/AEM.00756-16.

43. Wagner SJ. Virus inactivation in blood components by photoactive phenothiazine dyes. Transfus Med Rev. 2002;16(1):61-66. doi: 10.1053/tmrv.2002.29405.

44. Bachmann B, Knuver-Hopf J, Lambrecht B, Mohr H. Target structures for HIV-1 inactivation by methylene blue and light. J Med Virol. 1995;47(2):172-178. doi: 10.1002/ jmv.1890470211.

45. Shehatou C, Logunov SL, Dunman PM, Haidaris CG, Klubben WS. Characterizing the antimicrobial properties of $405 \mathrm{~nm}$ light and the Corning ${ }^{\oplus}$ light-diffusing fiber delivery system. Lasers Surg Med. 2019;51(10): 887-896. doi: $10.1002 / \mathrm{lsm} .23132$.

46. Chui C, Hiratsuka K, Aoki A, Takeuchi Y, Abiko Y, Izumi Y. Blue LED inhibits the growth of Porphyromonas gingivalis by suppressing the expression of genes associated with DNA replication and cell division. Lasers Surg Med. 2012;44(10):856-64. doi:10.1002/lsm.22090.

47. Dai T, Gupta A, Murray CK, Vrahas MS, Tegos GP, Hamblin MR. Blue light for infectious diseases: Propionibacterium acnes, Helicobacter pylori, and beyond? Drug Resist Updat. 2012;15(4):223-36. doi: 10.1016/j.drup.2012.07.001.

48. Lugongolo MY, Manoto SL, Ombinda-Lemboumba S, Maaza M, Mthunzi-Kufa P. The effects of low level laser therapy on both HIV-1 infected and uninfected TZM-bl cells. J Biophotonics. 2017;10(10):1335-44. doi: 10.1002/ jbio.201600217.

49. Lago ADN, Furtado GS, Ferreira OC, Diniz RS, Gonçalves LM. Resolution of herpes simplex in the nose wing region using photodynamic therapy and photobiomodulation. Photodiagnosis Photodyn Ther. 2018;23:237-9. doi: 10.1016/j.pdpdt.2018.06.007.

50. Huang YY, Chen AC, Carroll JD, Hamblin MR. Biphasic dose response in low level light therapy. Dose Response. 2009;7:358-83. doi: 10.2203/dose-response.09-027. Hamblin.
51. Kamani E, Razaghi MR. Application of laser blue light with a wavelength of $405 \mathrm{~nm}$ in the treatment of patients with the virus COVID-19. J Lasers Med Sci. 2020;11(4):361-362.

52. Sigman SA, MokmeliS, Monici M, Vetrici MA. A 57-year-old African American man with severe COVID-19 pneumonia who responded to supportive photobiomodulation therapy (PBMT): First use of PBMT in COVID-19. Am J Case Rep. 2020;21:e926779. doi: 10.12659/AJCR.926779.

53. Sigman SA, Mokmeli S, Vetrici MA. Adjunct low level laser therapy (LLLT) in a morbidly obese patient with severe COVID-19 pneumonia: A case report. Can J Respir Ther. 2020;56:52-56. doi: 10.29390/cjrt-2020-022.

54. Ailioaie C, Ailioaie L. Evidence for benefits of intervention with LLLT in children's asthma. Proceedings of the SPIE (society of photo-optical instrumentation engineers) sixth conference on optics; 2000 Sept 4-7; Bucharest, Romania. doi: $10.1117 / 12.432905$.

55. Ostronosova NS. [Outpatient use of laser therapy in bronchial asthma]. Ter Arkh. 2006;78(3):41-4. Russian.

56. Amirov NB. [Parameters of membrane permeability, microcirculation, external respiration, and trace element levels in the drug-laser treatment of pneumonia]. Ter Arkh. 2002;74(3):40-3. Russian.

57. Kochetov AM, Shelygina NM, Klodchenko NN, Zarembo IA. [The use of low-energy laser radiation in the combined treatment of patients with acute pneumonia]. Vrach Delo. 1990;2:70-1. Russian.

58. Aimbire F, de Oliveira AP, Albertini R, Correa JC, Ladeira de Campos CB, Lyon JP, et al. Low level laser therapy (LLLT) decreases pulmonary microvascular leakage, neutrophil influx and IL-1beta levels in airway and lung from rat subjected to LPS-induced inflammation. Inflammation. 2008;31(3):189-97. doi: 10.1007/s10753-008-9064-4.

59. Silva VR, Marcondes P, Silva M, Villaverde AB, CastroFaria-Neto HC, Vieira RP, et al. Low-level laser therapy inhibits bronchoconstriction, Th2 inflammation and airway remodeling in allergic asthma. Respir Physiol Neurobiol. 2014;194:37-48. doi: 10.1016/j.resp.2014.01.008.

60. de Lima FM, Vitoretti L, Coelho F, Albertini R, BreithauptFaloppa AC, de Lima WT, et al. Suppressive effect of lowlevel laser therapy on tracheal hyperresponsiveness and lung inflammation in rat subjected to intestinal ischemia and reperfusion. Lasers Med Sci. 2013;28(2):551-564. doi: 10.1007/s10103-012-1088-1.

61. da Cunha Moraes G, Vitoretti LB, de Brito AA, Alves CE, de Oliveira NC, Dos Santos Dias A, et al. Low-level laser therapy reduces lung inflammation in an experimental model of chronic obstructive pulmonary disease involving P2X7 receptor. Oxid Med Cell Longev. 2018;2018:6798238. doi: 10.1155/2018/6798238. 